\title{
100 Years of Wireless Telephony in Germany: Experimental Radio Transmission from Eberswalde and Königs Wusterhausen
}

\author{
Wolfgang Mathis ${ }^{1}$ and Anja Titze ${ }^{2}$ \\ ${ }^{1}$ DEI, Fakultät für Elektrotechnik und Informatik, Leibniz Universität Hannover, Hanover, Germany \\ ${ }^{2}$ Museum Eberswalde, Eberswalde, Germany \\ Correspondence: Wolfgang Mathis (mathis@tet.uni-hannover.de)
}

Received: 16 February 2021 - Revised: 2 August 2021 - Accepted: 13 August 2021 - Published: 17 December 2021

\begin{abstract}
In this contribution, we examine the development of radio technology before 1921 and the emergence of the broadcasting concept during the World War I. We consider in detail the experiments in the transmitter stations located in Eberswalde and Königs Wusterhausen and numerous sources in order to assess the importance of their work. We also discuss the question of whether the medium of broadcasting ("Rundfunk") started in Germany (or even in Europe) 100 years ago in one of these transmitter stations.
\end{abstract}

\section{Introduction}

On 11 November 1918, World War I ended after 1994 d and approximately 20 million soldiers and civilians died. Not only was it a war with weapons of a new quality, but new types of electrical communication systems were also deployed. In addition to the established wired communication technologies telegraphy and telephony, wireless communication systems were also successfully used for the first time in a great war (Maier, 2019). The Allied view that their own tube-based telegraphy and telephone systems became one of the most important factors in their ultimate victory by the end of World War I (Lavine, 1921). This is most likely a realistic interpretation of technical superiority of the Allies in the field of communication.

Before World War I, however, wireless telegraphy in Germany was comparable to wireless telegraphy in Great Britain and the United States, and German industrial companies were (world) market leaders in wireless telephony. In particular, C. Lorenz AG used patents for an electric arc transmitter of the Danish engineer Valdemar Poulsen and for an improved rotating high frequency machine of the German
Rudolf Goldschmidt of TH Darmstadt in order to investigate and further develop wireless telephony. For this purpose, C. Lorenz AG has set up an experimental station for electric arc transmitters in Eberswalde. Lorenz also set up a commercial station for their rotating high frequency machines in Eilvese near Hanover (HOMAG, 1919) while Telefunken operated one in Nauen (Telefunken Transradio, 1920). The Eberswalde station became crucial to the development of wireless telephony in the Imperial Navy. However, when World War I began, this technology was not used because it could be secretly monitored. The German Imperial Army built its own telegraph station in Königs Wusterhausen, which was in operation for military purposes from 1915 until the end of World War I.

After the end of World War I, wireless communication was no longer necessary for extensive military applications. However, the military and navy of all warring countries have been major customers for companies designing and manufacturing equipment for wireless transmitters and receivers. Therefore, companies were interested in new applications of communication technology previously used exclusively for the war. This led to the "radio" as a new communication media (in Germany "Rundfunk", Lerg, 1963, p. 20), that distributed or broadcasted voice information and music instead of point-to-point communication. In Germany, the situation was made even more difficult because the abdication of Wilhelm II caused plenty of confusion until a new constitution for the Weimar Republic, which was in the process of being built, was passed. Furthermore, there were various restrictions on the use of wireless technology due to the Versailles Treaty.

We outline here historical concepts for wireless telephony and describe the history of the transmitter stations in Eber- 
swalde and Königs Wusterhausen. We then will discuss in detail developments in these stations after World War I. In particular, we consider how inventions and broadcasting events from these stations have influenced upcoming broadcasting in Germany. It is emphasized that in this article we are only considering the period up to approximately 1921, since we are exploring whether the medium of broadcasting in Germany had already started in one of these stations before the official start of "Rundfunk" in Germany on October 29, 1923. For the history of the transmitter stations between 1921 and 1923, we refer to the literature (Suckow, 2008; Berger, 1998; Mathis, 2019).

\section{First Technical Concepts for Wireless Telephony}

Even before 1897, there were physicists and engineers studying the application of electromagnetic waves that Heinrich Hertz discovered in 1886-1887 (Hertz, 1892). However, Marconi was the first to popularize these waves in wireless telegraphy (Wolfschmidt, 2008). Adolf Slaby, professor of electrical engineering at the $\mathrm{TH}$ Charlottenburg in Berlin, was invited to Marconi's experiments by William Preece, the Engineer-in-Chief of the British General Post Office in London. When he returned to Berlin, he reconstructed Marconi's transmitter and receiver, which may be interpreted as espionage (König, 2007, p. 53). As early as 1897, Slaby demonstrated Marconi's wireless telegraphy to the German Kaiser Wilhelm II (Schott, 1925, p. 34; König, 2007, p. 53; Stock, 2011, pp. 20-21). In 1899, the imperial German armed forces began to experiment with wireless radio transmitters (Thiele, 1925, p. 219), using Ferdinand Braun's concept of resonance which led to a significant improvement in the range of Marconi's radio transmitters (Jentsch, 1904, pp. 77-80). In 1902, a first wireless telegraphy department was established in the airship battalion ("Funkentelegraphenableitung" at the "Luftschifferbatallion") and in 1905, a wireless telegraphy department was established in Telegraph Battalion 1 (Stock, 2011, p. 25).

The Hertz arrangement generates damped electromagnetic waves and Marconi's transmitter used this concept. The possibility of generating continuous electromagnetic waves was discussed by the Irish physicist George Francis FitzGerald as early as 1892 (FitzGerald, 1892). He mainly described the use of dynamos and electrical machines for this purpose. Based on this principle, several papers about the usage of spark-based generators of continuous electromagnetic waves. In particular, the properties of a constantly burning arc have been studied by William Ayrton and his wife Hertha Ayrton. These studies pointed out that "negative resistance" became a crucial issue (Ayrton, 1902; Thompson, 1896). Furthermore, Hermann T. Simon (Simon, 1898) and later his research group (Heinrich Barkhausen, Karl Willy Wagner, Gertrud Lange) in Göttingen intensively examined the arc.
After wireless telegraphy with damped waves became a useful communication medium alongside the wired telegraphy where information was transmitted in coded form from a transmitter to a desired recipient, first ideas for implementing wireless point-to-point telephony were seriously discussed around 1905. A very promising method based on William Du Bois Duddel's research was developed by Danish engineer Valdemar Poulsen (Poulsen, 1903). Duddel, a student of William Ayrton at London Central Technical College, showed experimentally that an arc may be used as negative resistance to generate continuous acoustic waves (Duddel, 1900).

On Easter 1906, Count Georg von Arco and Eugen Nesper from the Telefunken company had the opportunity to personally inspect Poulsen's innovative radio transmitter in Copenhagen. AEG's managing director Emil Rathenau, a partner in Telefunken, turned down Poulsen's offer to buy his patent rights. Rathenau believed that it was possible to circumvent Poulsen's patent with the help of Simon's group in Göttingen. It turned out he was wrong (Nesper, 1950, pp. 49-50). Poulsen founded the Amalgamated Radio Telegraph Company Ltd. with a British investor, but after this company was unsuccessful, C. Lorenz AG, who had been active in the telephone business, took over Poulsen's patent rights in 1908. A department of wireless telegraphy was founded (Lorenz, 1930, pp. 197-227) where mobile transmitter stations for the imperial army and for the imperial navy were developed (Lorenz, 1930, p. 198). The now obsolete Braun-Marconi stations of the Gesellschaft für drahtlose Telegraphie, System Telefunken, were replaced in 1909 by arc transmitters based on the Poulsen principle operated by C. Lorenz AG (Stock, 2011, p. 27).

The success of Lorenz caused economic problems for Telefunken (König, 2007, p. 65). In 1908, Telefunken presented an alternative and successful concept with the spark gap transmitter ("Löschfunkensender") that was based on ideas from Max Wien (Friedewald, 1999). In 1911, it became clear that radio-gap transmission stations are more suitable for mobile military use than Lorenz-Poulsen transmission stations (Schott, 1925, p. 44).

In his 1892 paper, Already FitzGerald discussed the application of rotating machines for the generation of continuous electromagnetic waves. However, Ernst Frederick Werner Alexanderson was the first who developed such a machine which was used by Reginald Fessenden for his transmitting sound by radio waves (Seitz, 1999). The high frequency machine from Alexanderson had the disadvantage that the number of rotations was very high. The concept from Rudolf Goldschmidt therefore represented a significant improvement (Goldschmidt, 1907). Goldschmidt offered Telefunken the right to use his patent, but Georg Graf von Arco refused (Nesper, 1950, p. 58) and developed his own concept of a high frequency machine together with Alexander Meißner (Meißner, 1953). Finally, the rights to use Goldschmidt's patents were taken over by the C. Lorenz AG, 
which founded the Hochfrequenzmaschinen A.G. (HOMAG) to exploit Goldschmidt's patents (Nesper, 1950, pp. 58-62; Herold, 2002, pp. 49-53).

\section{Experimental Transmitter Station of the C. Lorenz AG in Eberswalde}

When Telefunken decided to reject the Poulsen transmitter concept, several engineers left the company and joined the department of wireless telegraphy of C. Lorenz AG (Nesper, 1950, pp. 54-55). Therefore, in 1906 Lorenz was able to start the newly founded department with experienced engineers such as Otto Scheller, Walter Hahnemann, and Eugen Nesper (Lorenz, 1930, pp. 197-199; Goebel, 1983). The wireless telegraphy department was placed at the Lorenz's factory site in Berlin Elisabeth-Ufer 5/6 (Lorenz, 1930, p. 62). First orders for Lorenz Poulsen broadcasting stations were placed by the Imperial Navy. Therefore, this topic was classified as absolutely secret (Nesper, 1950, pp. 56-57) and secrecy was maintained until well after World War I (SEG, 1934). there was constant dispute in the laboratory (Nesper, 1950, pp. 63-64). Furthermore, on Lorenz's Berlin factory site was not suitable for any experiments with large antennas that would have been necessary to achieve larger transmission ranges (Klawitter, 2002, p. 88). Therefore, Nesper, who was responsible for naval orders, decided to set up an external laboratory in Eberwalde to carry out military tasks (Nesper, 1950, p. 64).

Nesper negotiated with the mayor of Eberswalde about a suitable (and inexpensive) area for the new laboratory. On 1 April 1909, took a lease on the $17500 \mathrm{~m}^{2}$ "Bullenwiese", the former city meadow. (Berger, 1998, pp. 19-21). The construction work began immediately. A $70 \mathrm{~m}$ high wooden lattice mast according to de Forest's concept (Nesper, 1921, p. 169,182$)$ as a central antenna mast and 16 additional masts at a distance of $117 \mathrm{~m}$ as well as several laboratory buildings were erected. Finally, on 27 October 1909, the experimental station officially began operating. On 10 November 1909, a construction worker reported the details about the station in the newspaper "Berliner Lokalanzeiger" (Berger, 1998, pp. 28-34). The station is shown in Fig. 1.

From then, Lorenz employees researched and developed the details of the Lorenz-Poulsen transmitter and its properties regarding the transmission of speech with the electromagnetic waves generated by the transmitter. Robert Herzog was the station manager and the station crew consisted of the engineers C. L. Vrany, R. Hartenstein, Bräschke, and a few others (Nesper, 1950, p. 64). Furthermore, before Lorenz's HOMAG transmitter station in Eilvese near Hannover was built in 1912, Goldschmidt's high frequency machine was first installed in Eberswalde in 1910. In the Winter of 1910/11, Prince Heinrich von Preussen visited Eberswalde in order to inspect the new kind of high frequency machine for the first time (Nesper, 1950, p. 65; Berger, 1998, pp. 45-
48). Furthermore, experiments were carried out with Hans Rein's multi-tone ("Vielton") transmitter, a variant of the spark-gap transmitter concept by von Lepel-Burstyn (Nesper, 1950, pp. 62-63; Berger, 1998, p. 49). In 1912, other special applications of the Lorenz-Poulsen transmitter were investigated in the Eberswalde station such as the use of highfrequency electromagnetic high-power waves to melt metals and the penetration of electromagnetic waves into human tissue to generate internal heat ("diathermy") for medical purposes (Nesper, 1950, p. 63; Berger, 1998, p. 50). Perhaps the best-known research result is a modulation device based on a nonlinear inductance ("Pungs-Drossel") developed for Goldschmidt's high frequency machines by Leo Pungs in 1913 (Berger, 1998, p. 49; Nestel, 1983). Pungs explained later on: "In these experiments the high frequency energy was modulated by speech and music". After World War I, he continued his research on the Pungs-Drossel and used its for the modulation of Lorenz-Poulsen transmitters (Pungs, 1913, 1961).

On 1 August 1914, at the beginning of the World War I, the Eberswalde transmitting station was closed by the Imperial Ministry of War, the antenna was connected to earth, and the station was guarded day and night. On 1 August 1918, only shortly before the end of World War I, was Lorenz's station in Eberwalde allowed to resume experiments for military purposes (Berger, 1998, pp. 52-53). Further details may be found in Mathis (2019) and the companion book of the exhibition "Communication with Electrical Current: Telephone and Broadcasting" in the museum in Eberswalde (Museum Eberswalde, 2020).

\section{Transmitter Station of the German Reichspost in Königs Wusterhausen}

Telefunken's spark-gap transmitter proved to be more suitable for mobile military use (Schott, 1925, p. 44). Trials with Telefunken's mobile spark-gap transmitters ("Feldstationen") showed that they were particularly suitable for military use (Maier, 2019, pp. 40-41). These experiments also took place in König Wusterhausen, among others (Suckow, 2008, p. 9). The intention for conducting these experiments was to find a suitable place for the central radio station of the German armed forces near Berlin. It was most important that there was no interference of electromagnetic waves with the large transmitter station in Nauen (see Fig. 3) and at the same time an optimal transmission of waves. In contrast to the German armed forces, the Imperial German Navy already operated its own wireless telegraph stations, e.g. in Bülk (Kiel) and Arkona on the island of Rügen (Thurn, 1910). At the beginning of World War I, transmitter stations such as "Norddeich" and "Nauen", which previously served civil communication purposes with ships, were now taken over by the Navy (Claussen and Nanninga, 1957; Schott, 1925, p. 64). However, the commander of the army mainly considered the telegraph station at the Eiffel Tower in Paris as their model: "The 


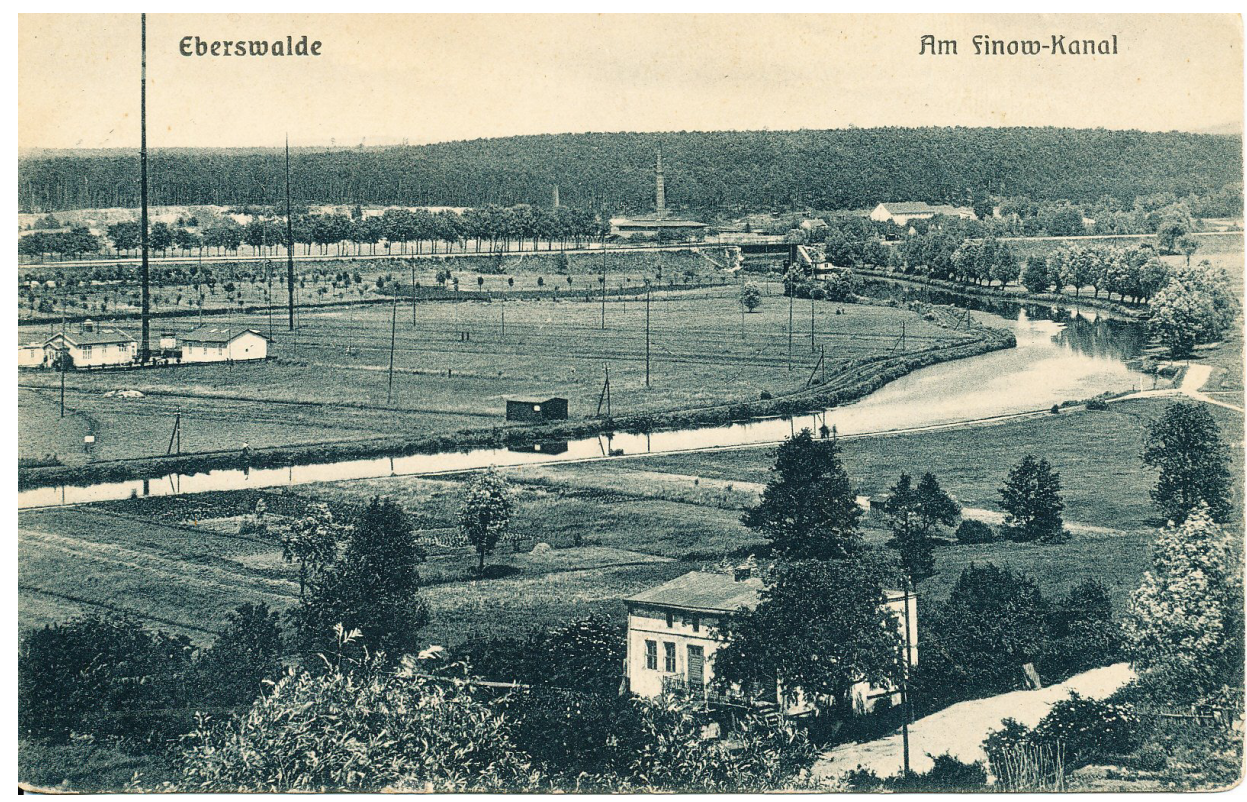

Figure 1. Wireless Transmitter Station in Eberswalde (1918).

paramount importance of the Eiffel Tower station made the construction of a large central station, which could direct and mediate the transmission of information in the country during a war desirable. Such a station was planned in Königswusterhausen" (Schott, 1925, pp. 63, 91). It appears that a blueprint of the buildings for the 5th Military Unit ("Kompanie") of the Telegraph Battalion was completed in 1912 (Suckow, 2008, p. 10), but the final decision to build the station in Königs Wusterhausen was not made until 1 October 1913 (Schott, 1925, pp. 58-60; Manteuffel, 1998, p. 62). The army's proposal contained 1.5 million German Mark, although a large broadcasting station cost only 400000 German Mark at that time (Schott, 1925, p. 63). The troop accommodation and the associated buildings were built until the end of 1913, but construction of the transmitter station was delayed with the beginning of World War I, as many construction workers were called up for military service (Manteuffel, 1998, pp. 62).

Cavalry captain ("Rittmeister") Egbert von Lepel became commander of the Königs Wusterhausen station, probably at the beginning of the World War I. The station is shown in Fig. 2. He was an expert in wireless telegraphy and was employed by the company for wireless telegraphy, System Telefunken (25 years Telefunken, p. 309) from 1904 to 1906 . He then invented a "device for generating rapid electrical oscillations" (DRP 232174 in 1907 and US patent 1043117 in 1912 - filed in 1908), where he set up a company in Berlin to manufacture transmitters based on his patent. He later sold his rights to the patent to a British syndicate, which used it in the US and other countries. In 1911, von Lepel received the patent for the spark-gap transmitter ("Löschfunkensender") from the Imperial Patent Office and thus prevented Telefunken for obtaining a patent for it (The Times, 1911). Since von Lepel was annoyed about the slow construction process of the transmitter buildings in Königs Wusterhausen, he ordered the baracks for the wireless telegraphy equipment to be built first (Suckow, 2008, pp. 10-11). Then he started experimenting with a rotary gap transmitter and a simple antenna consisting of a $150 \mathrm{~m}$ wire (Manteuffel, 1998, p. 63).

Work on the transmitter building began in August 1915 (Telefunken Zeitung, 1919, p. 35) and was certainly completed by the end of the year. It is known that the telegram traffic between the transmitter station in Madrid-Carabanchel (Telefunken Zeitung, 1912, p. 81-82) and the Norddeich station was discontinued and that this service was taken over on 9 January 1916 by the Königs Wusterhausen station (Claussen and Nanninga, 1957, p. 20). However, the author of an article in the Telefunken-Zeitung (first edition after the World War I) from 1919 mentioned that the station opened its service in April 1916 (Telefunken Zeitung, 1919) whereas the Funkerberg museum in Königs Wusterhausen denoted that the transmitter station opened at 15 June 1916 as "Zentralfunkstelle des Heeres" (Suckow, 2008, p. 11).

With respect to the transmitter building, we can find the following in the "Telefunken-Zeitung" (Telefunken Zeitung, 1919): "The purely external arrangement has also given the station a special and characteristic appearance. Since it was assumed that the station would be attacked by enemy planes, the buildings are half set in the ground and the ceilings are made of thick cement to make them bombproof. The same applies to the power plant, that, in addition to water and air cooling, had large fans built in for the crude oil engines, which are also housed bombproof. Only the antenna towers could not be protected directly against air attacks" (Telefunken Zeitung, 1919; Thurn, 1920). 


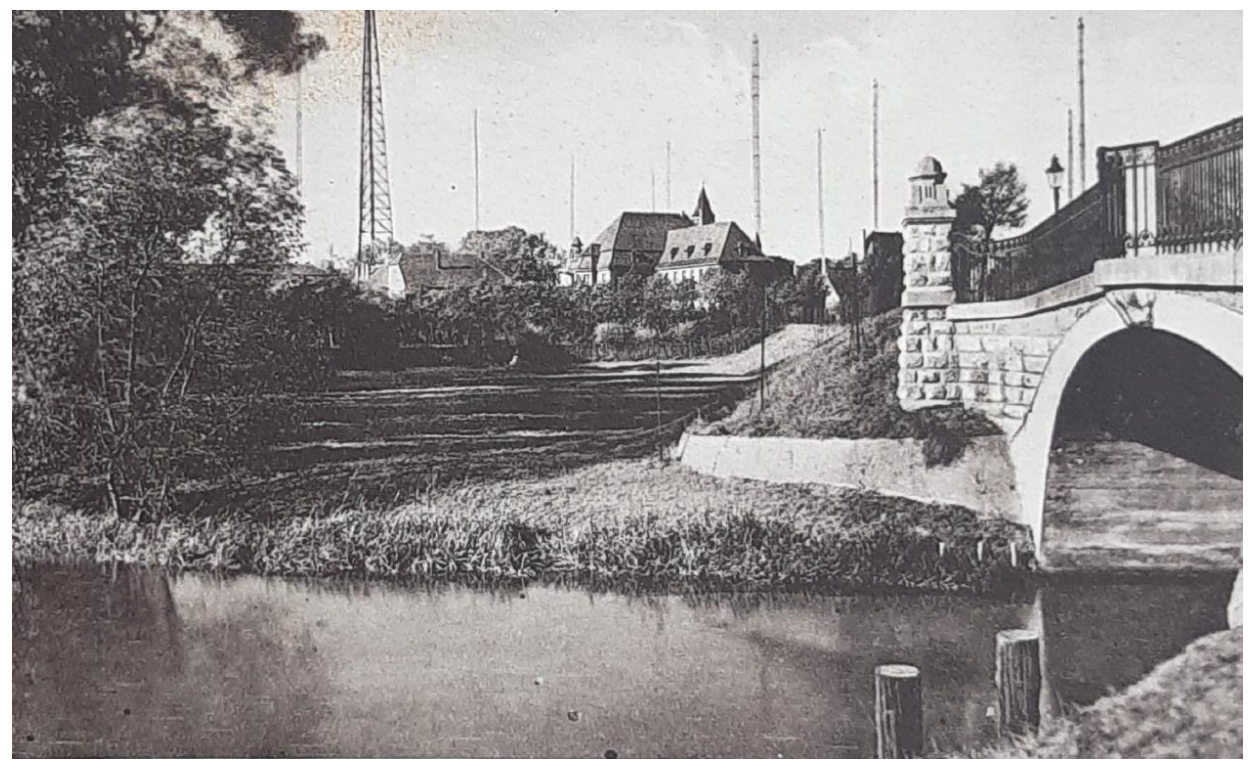

Figure 2. Wireless Transmitter Station in Königs Wusterhausen (1930).

It is known that there were two spark-gap transmitters from Telefunken and two Poulsen transmitters from C. Lorenz AG in the Königs Wusterhausen transmitter station. The outputs of the spark-gap transmitters are stated in literature as 70 and $5 \mathrm{~kW}$, but there are different output values of the Poulsen transmitters: (Telefunken Zeitung, 1919): 35 and $5 \mathrm{~kW}$ (Thurn, 1920; Suckow, 2008): 32 and $5 \mathrm{~kW}$. (Gerlach, 1930): 32 and $10 \mathrm{~kW}$. (Berger, 1998): 32 and $4 \mathrm{~kW}$, Berger quoted the values from an official letter in the files of the Reichspost. Since the photographs of the two Poulsen transmitters in Thurn (1920) and Gerlach (1930) differ significantly, it is impossible to get a clear picture of the structure of these transmitters in Königs Wusterhausen. An explanation why two spark-gap transmitters and two Lorenz-Poulsen transmitters were used may be found in an article paper by Schott (Schott, 1925, p. 62): "The radio stations in the larger fortresses were large radio stations with three receivers and two transmitters. The combination of an undamped [Poulsen] and a spark gap transmitter proved to be very advantageous. An undamped system has the advantage of great tuning precision, so that the stations were easily able to avoid simultaneous traffic of other stations by choosing a wavelength that differs by only a few percent. The spark-gap system penetrates more sharply and, in particular, is more independent of atmospheric disturbances." Some details about the antenna system are also known: "The large L-antenna is in two sections, which may be used individually or together, on five masts of $150 \mathrm{~m}$ each fixed height. There are also two smaller T-antennas which may be switched separately or together" (Telefunken Zeitung, 1919).

The transmitting station in Königs Wusterhausen was given the station name "LP" (Strauß, 1925, p. 77), which referred to the station commander Egbert von Lepel. Probably in April 1917, he had to leave Königs Wusterhausen and was assigned to the High Command of the 1st Imperial Army on the Western Front (Pressestelle, 1917), whose headquarters were relocated to Rethel near Reims on April 12, 1917 (Cron, 1937, p. 79; Ludendorff, 1919, p. 325).

As mentioned above, Königs Wusterhausen served as the central broadcasting station for the exchange of military information within Germany, but at the end of World War I it sent military reports "to all stations" ("an alle"). On 4 November 1918, sailors of the Imperial Navy rebelled against their naval officers, occupied this broadcasting station (Dahl, 1978, p. 15), and the so-called November Revolution began. The revolutionary workers' and soldiers' councils founded a Central Radio Committee ZFL ("Zentralfunkleitung") that broadcast messages via the transmitter in Königs Wusterhausen (Lerg, 1963, p. 49; Gilfillan, 2009, p. 30). In Berlin, Wolff's Telegraphic Bureau was occupied by them to control information. However, the former radio operators of the ZFL were unable to organize wireless telephony in Germany that was independent of the government or the Ministry of Post and Telegraphy (Lerg, 1963, pp. 4572; Gilfillan, 2009, p. 32). Hans Bredow later describes the ZFL's attempt to set up a government-independent system of wireless telephone stations as "Funkerspuk" (which means something like: spook of radio operators or specter of the radio operator (Gilfillan, 2009, p. 31; Hagen, 2005, pp. 67-68). In the end, the newly established German Radio Commission ("Reichsfunkkommission" (RFK)) was completely under the control of the German Post Office ("Reichspostamt" (RPA)) and thus the Ministry of Post and Telegraphy. Finally, the director of Telefunken, Hans Bredow, who had previously worked as a consultant for the RFK, became president of the RFK on 21 January 1919. On 1 March 1919, he became 
director of wireless telegraphs at the RPA (Soppe, 1976, p. 123). This further development shows that the elections for the National Assembly in Germany on 19 January 1919 also marked the end of the influence of the workers' and soldiers' councils and that the large transmitter stations such as these Nauen or Königs Wusterhausen were again in the hands of the RPA.

\section{Wireless Communication: Conversion from Military to Civilian Application}

The political controversy over wireless telegraphy proves that it had the potential to be a major factor in the emerging German republic. Already in 16 January 1919 the RPA formulated a memorandum about their position with respect to the "Development and comprehensive design of wireless telegraphy for general communications". The RPA made it clear that it claimed all wireless telegraphy equipment and transmitter stations that were subordinate to other government agencies during World War I, which, of course, aimed at the military authorities (Lerg, 1963, pp. 73-76). After a rather complicated political discussion, the German interim government and its Prime Minister Philip Scheidemann confirmed the takeover of wireless telegraphy by the German Post (Lerg, 1963, pp. 76-83). The director of the newly formed department for wireless telegraphy was Hans Bredow. That meant that the sovereign administration and the operational administration were in one hand (Lerg, 1963, p. 80).

Obviously, assigning a former director of the largest wireless telephony company in Germany wireless telephony was problematic for the other companies, especially for C. Lorenz AG. A lecture by Otto Betz, the senior manager of "Drahtlose Übersee-Verkehr A.G.", on the occasion of the Telefunken exhibition about the development of wireless communication during the World War I (Nairz, 1919), formulated concerns of other wireless communication companies. He explained that wireless communication is very useful for the press, as it is possible to transmit information in all directions [with respect to the transmitter] - a clear interpretation in terms of broadcasting. In addition, he suggested that the operational management should be with a private company. The C. Lorenz AG interpreted Betz's lecture in such a way that he meant Telefunken and wrote a protest note to the German government, but received a meaningless response and was referred to decisions of the new government (Lerg, 1963, pp. 76-83). It must be emphasized, however, that there was not yet a clear understanding of the use of wireless communications in the RPA. For example, Hermann Thurn, who has been publishing as trainee of the German Post ("Ober-PostPraktikant") about the latest developments in wireless telegraphy already since 1910, discussed their application in the field of commercial telegraphy and radio direction finding in the article "The German wireless telegraphy in the World
War I" from 1919 (Thurn, 1919a). He also warned of severe restrictions on wireless telegraphy for Germany in an upcoming peace treaty. Even though wireless telephones could be used for international communication, distribution to private recipients is not addressed, instead he suggested that the exchange should take place between the large transmitting stations.

Indeed, the Versailles Treaty of 28 June 1919 contained such restrictions and therefore the German military had to abandon all of its large wireless telegraph and telephone stations (Thurn, 1919b). This was not a serious problem for the experimental broadcasting station in Eberswalde, as it was reopened at 1 August 1918 and returned to C. Lorenz AG after the end of World War I. As former military radio transmitter station, Königs Wusterhausen had to be separated from the military so that the station could continue to operate (Lembke, 1970, p. 102).

Little is known about the events in both broadcasting stations in 1919 and early 1920, but there is no doubt that both Eberswalde and Königs Wusterhausen were active in the field of wireless technology. Leo Pungs and Felix Gerth had returned from the war to continue their work in Eberswalde. With the remaining team and under the direction of Robert Herzog, they worked on improvements to wireless telephony with Lorenz-Poulsen transmitters. At the beginning of 1919 the transmission was supposed to be interrupted by the German War Ministry, but then the responsibility changed to RPA and engineers of the C. Lorenz AG were allowed to continue working on long wave and medium wave (MW) transmission (Berger, 1998, p. 53). Pungs continued working again on his modulation device, developed in 1913 and implemented in a high-frequency machine transmitter. Pungs and Gerth combined it with a Lorenz-Poulsen transmitter (Pungs, 1923). As a result, the voice transmission was improved significantly, whereby, as in 1913, music from a gramophone was also transmitted in order to avoid the tiresome speech test (Nesper, 1950, p. 58). Another important step was the development of a new type of microphone that did not have any disruptive resonances which were common with the carbon microphones that were typically used for wireless telephony at the time. Hans Harbich, a former engineer from the C. Lorenz AG and Post Council at the time, advised the managing director of the C. Lorenz AG, Robert Held, that the "Kathodophon" would also be suitable for high quality wireless telephony. This microphone was originally developed by Joseph Masolle, Joseph Benedikt Engl and Hans Vogt for the sound film and they founded a company to develop their Tri-Ergon system. Lorenz supported their company and secured the use of the Kathodophon (Naber, 2006, pp. 10-12). From 1921 this type of microphone was used for transmissions with the Eberswalde transmitter (Berger, 1998, pp. 57-60). The first public presentation of the Kathodophon was given by Pungs in 1922 (Pungs, 1922).

After the revolutionary workers'and soldiers' councils left the transmitter in Königs Wusterhausen at the end of 1918, 
the technical team around its station manager Walter Mehle was apparently more or less able to act independently. In his autobiography Nesper mentioned that Mehle had transmitted speech and music to him in Vienna with one of the Lorenz Poulsen transmitters in January or February 1919. At the repetition of this experiment on the occasion of a lecture in Vienna in mid-March 1919 in front of 700 people (Nesper, 1950, p. 91), Nesper used a self-constructed 7-tube receiver ("press receiver"). Urged by Ludendorff, he became director of the local C. Lorenz AG branch in Vienna in July 1917 (Nesper, 1950, p. 80). Later on, Nesper informed Bredow about his experiments and results and pointed out that the transmitter stations in Königs Wusterhausen, Nauen, Eberswalde, and Eilvese (near Hanover) were ready to provide "Telefony for all", but Bredow did not seem interested (Nesper, 1950, pp. 91-92). Today, however, we know from the RPA files that negotiations with C. Lorenz AG about the use of the transmitter in Eberswalde were started in July 1919, but failed due to the company's high monetary demands (Berger, 1998, p. 55).

On 27 September 1919, the Königs Wusterhausen station was taken over by the RPA (Berger, 1998, p. 55; ETZ Message, 1919). The future of the transmitter station in Königs Wusterhausen was already determined in June 1920: According to a decision by the RPA, Königs Wusterhausen should be be the transmitter station that should be supplied with signals by cable from the central radio transmitter station in Berlin (Thurn, 1920, p. 38). Later on, the Königs Wusterhausen station was used in Bredow's concept of a commercial wireless business broadcast service ("drahtloser WirtschaftsRundspruchdienst"). Bredow announced this service in his URANIA lecture in 1919 (Lerg, 1963, pp. 93-96) and implemented as a wireless telegraph service. The technical details of the implementation were described by Thurn (1921a). Thurn also mentioned that [at the end of] 1919 and in cooperation with C. Lorenz AG, wireless telephony was successfully tested in Königs Wusterhausen. Wireless telephony had the advantage that little knowledge was required to operate the receivers. Although the broadcasting concept was characterized very clearly ("Supply any number of receiving points with messages by sending them once") - denoted as "Rundfunk" - entertainment broadcasting ("broadcasting for all") was not addressed. Broadcasting was understood exclusively as a service for the economy.

The wireless transmission experiments were mainly aimed at receiving stations of the RPA, since almost no private persons had receiving devices. However, there were numerous foreign broadcasters who sent confirmations to Königs Wusterhausen (Mehle, 1955). On 22 December 1920 the famous "Christmas Concert" was sent, which was presented by a group of musicians from Königs Wusterhausen, among them the technician Erich Schwarzkopf (Funk, 1927), who played the violin. A detailed description of the musicians and the enthusiastic confirmations is included in (Suckow, 2008, pp. 19-21). On 1 February 1921 the former naval offi- cer Hans Gerlach became the new station manager in Königs Wusterhausen , and received the title of "Telegraph Director" (Lembke, 1970, p. 105). He supported the transmission tests of wireless telephony and the concerts (Gerlach, 1930). On 8 June 1921, the opera "Madam Butterfly" was transmitted live from the Berlin State Opera. The legendary broadcast was conducted by Postal Council W. Hahn (Schwarzkopf, 1924; Mehle, 1955; Suckow, 2008, p. 22).

For the transmission experiments described, a $4 \mathrm{~kW}$ Lorenz-Poulsen transmitter with Pungs modulation device was used, which the C. Lorenz AG supplied in addition to the Lorenz-Poulsen transmitters already available in Königs Wusterhausen (Gerlach, 1930). A Lorenz-Poulsen transmitter is, however, very complicated to handle in operational use (Weichart, 1997, pp. 202-203), which is why Friedrich Weichart describes it as a "stubborn donkey". It is not suitable for continuous operation and, moreover, it can only be operated sensibly with very long waves. Due to these challenges, a Lorenz-Poulsen transmitters were not a sound technical basis for the broadcasting medium ("Rundfunk"). By the way, Weichart developed the first tube transmitter in 1923, which was used for the official opening of the medium broadcasting ("Rundfunk") in Germany on 29 October 1923 (Weichart, 1930). It was not easy to keep the Lorenz-Poulsen transmitter in operation which is why the Lorenz employees Pungs and Gerth were probably present at the Königs Wusterhausen transmitter station at least during broadcasts.

\section{From Wireless Telephony Experiments to the Medium of "Broadcasting"}

In the previous sections it was shown that systematic experiments with wireless telephony in Germany were carried out for the first time in the transmitter stations in Eberswalde and in Königs Wusterhausen. Figure 3 shows that both stations were located near Berlin. C. Lorenz AG worked on wireless telephony and improvements Lorenz-Poulsen transmitters in their experimental transmission station until the beginning of World War I. The company continued this work immediately after the end of the war and also carried out transmission experiments with speech and music.

The Lorenz-Poulsen transmitters for the telegraph service in the former military transmitter station in Königs Wusterhausen were also suitable for wireless telephony and once the station was no longer strictly monitored by the authorities, the station employees used this option at least occasionally. With the official takeover of the transmitter station in Königs Wusterhausen by the RPA, it again received a clear mandate, namely to be the central station of a commercial Germany-wide communication network. However, experiments on wireless telephony were also carried out with the idea in mind that this could later be useful for this communication network. Thanks to the station managers Mehle and Gerlach, not only were technically justifiable experiments 


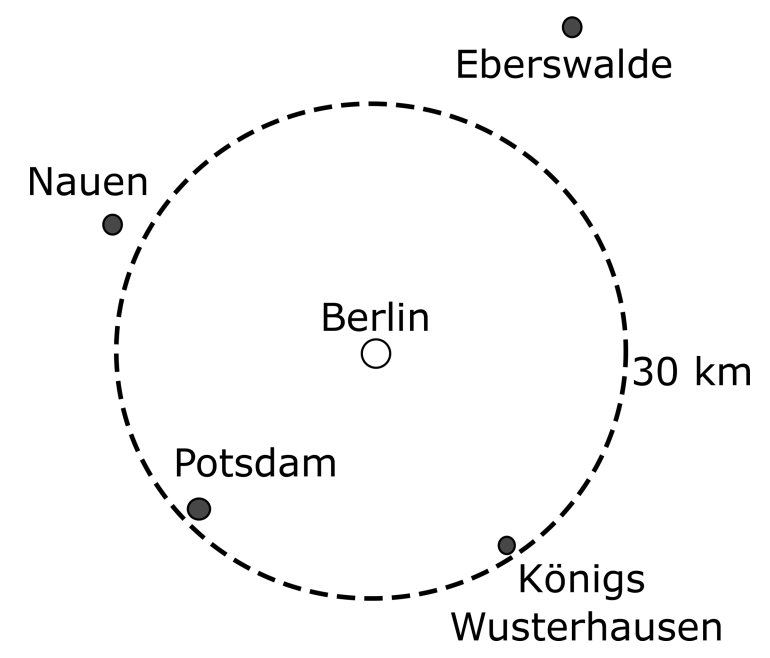

Figure 3. The Berlin area with the locations of wireless transmitter stations.

carried out, but concerts were also broadcast. The Christmas concert of December 1920 achieved wide recognition and in the summer of 1921 even an opera event was transmitted, containing elements of entertainment.

But can these activities in Eberswalde and Königs Wusterhausen be called the beginnings of the medium of broadcasting? First of all, we have to emphasize that the idea of broadcasting arose during World War I, although the first steps towards broadcasting entertainment were taken before the war (e.g. Reginald Fessenden (Kintner, 1932), Egbert von Lepel (Star Tribune, 1909), Lee De Forest and Georg Seibt (de Forest and Seibt, 1910) in the USA). The broadcasting of music has also been discussed in US magazines for radio amateurs (e.g. Marple, 1916). At the end of World War I, the broadcasting concept was used by all warring sides for propaganda purposes (Soppe, 1976, pp. 121-122). In the US, the conversion of military to civil use of broadcasting was discussed as well. In February 1919 "the development of the art of radio telephony by the American Telephone and Telegraph Company and the Western Electric Company" were discussed by Craft and Colpitts who ran the two main suppliers of the Allies' military equipment, American Telephone an Telepgraph Company and Western Electric Company. At the end of their article (Craft and Colpitts, 1919), they enumerate three cases of civilian applications and the third was described as: "A third class of service is that which is concerned, not with single individuals, but with groups; such service as the broadcasting of news, time and weather signals, and warnings. In some cases, a [former] disadvantage of radio telephony [namely, not being secret] would be an advantage in this class of applications". It was therefore not surprising that Siegfried Loewe, later head of a radio company in Berlin, described in September 1920 what great opportunities radio amateurs in the USA had compared to those in Germany. Loewe then also developed his far-reaching ideas about the future of the radio medium (Nesper, 1923, pp. 3-4). At the end of World War I there were 4381 officers and 185000 soldiers in the army signal units ("Nachrichtentruppe") who had the knowledge to further pursue radio telephony (Beuttel, 1925; Lerg, 1963, p. 43, pp. 85-91; Dahl, 1978, pp. 17-18; Gilfillan, 2009, pp. 35-36).

The question still remains whether at least the beginning of the broadcast medium in Germany can be located in Eberswalde and Königs Wusterhausen. Well-known technology historian and radio communications expert Winfried Lerg answered this question in 1994, which is so concise that it should be reproduced here (Lerg, 1994):

The "Telephony Experiments" with experimentally varied word, song and music performances were subsequently described as "radio premieres" by some participants and witnesses in memorial contributions. In this case, the reasons for these historical misinterpretations are to be found in the fact that on the one hand the transmission is a systematic premise of the mediation, and that, on the other hand the formulation of the transmitted (voices and tones) constitutes the formality of the transmitted (word, music) at the same time. The re-narration becomes an action without course in which a crucial difference between the transmission structure "radio" (channel) and the transmission structure "broadcast" (medium) is overlooked. In wireless telephony, the function of communicators as well as recipients differ from those in broadcasting. Experimental radio operators test the transmission quality under changing conditions. Feedback from colleagues in other test stations or from amateurs is essential for the test result. These in turn receive the test broadcasts - for pleasure or for technical reasons -, check the reception quality under changing conditions and submit the results to test stations or other amateurs. In contrast, the functions of communicators and recipients in the medium of broadcasting - are determined completely differently. Thy mainly concern informative, opinion-forming, social and entertainment purposes.

Winfried Lerg argued against statements such as "wireless telephony experiments in Eberswalde ("still in 1919") and in Königs Wusterhausen ("early in 1920") represented the first really successful experiments in the transmission of speech and music, and thus the beginning of broadcasting in Europe" (text of an exhibition brochure of the museum Eberswalde 1993 cited in Lerg, 1994, p. 128) because "these statements can neither be justified from the perspective of the history of technology nor the history of broadcasting" (Lerg, 1994, p. 128). Furthermore, we have to emphasize that this was not the beginning of broadcasting in Europe because the first music broadcast took place on 6 November 1919, when 
the Dutch engineer Schotanus é Steringa Idzerda broadcast as live concert a "Soiré Musical" from the Public House in Scheveningen. The government of the Netherlands had granted him an broadcasting license on 14 August 1919. His broadcast was even received in parts of Scotland and the south east of England (de Boer, 1969).

We have to add a few more statements about the role of Hans Bredow, who, in 1928, was the first to popularize the statement about "Königs Wusterhausen as the "cradle" of broadcasting in Europe" (Bredow, 1928). It is known at least since 1963, when the substantial monograph about the history of broadcasting in Germany was published by Lerg (1963), that Bredow's statements about the development of broadcasting in Germany must be viewed critically. A main reason is that Bredow had, from the beginning of his professional career, already sketched an advantageous picture of himself in numerous articles and some books (Bredow, 1927, 1954, 1956). In these publications he presented his intentions at the time with regard to broadcasting in a way that does not readily stand up to a detailed historical analysis. Unfortunately, this was not fully recognized before Lerg's monograph and is rarely discussed until now, at least in the public media. With regard to the "difficulties" (Winfried Lerg) in producing a consistent biographical assessment of Hans Bredow, we would like to refer to some literature (Lerg, 1980; Ross, 1966; König, 2007, pp. 240-241). In this context, we refer also to the statements made by Friedrich Weichart, who worked closely with Bredow in the early 1920 s (Weichart, 1997, p. 206). Detailed arguments may be found in (Mathis, 2019) that Bredow as well as Georg Graf von Arco avoided to mention achievements of C. Lorenz AG whenever possible and, in particular, they never mentioned the transmitter station in Eberswalde in their publications.

Finally, the further development of the transmitter stations in Eberswalde and Königs Wusterhausen should be discussed briefly. The employees of C. Lorenz AG in Eberswalde continued to work improving the Lorenz-Poulsen transmitter for a while, focusing on the use of the "Kathodophon". At the beginning of January 1923, the increase in quality through this microphone was demonstrated with the help of an orchestra made up of citizens of Eberswalde. Again, there were numerous positive reactions from at home and abroad. When the transmitter station in Eberswalde broadcast political news about the military occupation of the Ruhr area, french authorities disagreed and decided to transmit a jamming signal from the Eiffel tower. This became known at least locally as "The Spook of Eberswalde" (Berger, 1998, pp. 61-73). Numerous concerts were presented by the Eberswalde orchestra, the last of which was reported in the newspaper on 11 January 1925 (Berger, 1998, p. 77). Probably, one of the most interesting and successful concerts was a double transmission to an event at Deutsches Museum (Munich), where the sound of the transmission with the "Kathodophon" used in Eberswalde and the one conducted with the carbon microphone used in Königs Wusterhausen were compared to each other (Berger, 1998, p. 74). It finally turned out that in broadcast technology the Reisz microphone was superior to the "Kathodophon" and the instability-prone LorenzPoulsen transmitter was no serious competitor for the electron tube transmitters. Since the antenna system was optimized for Lorenz-Poulsen transmitters, the transmitter station quickly lost its importance when electron tube transmitters were widely used. In the following years only a few activities such as experiments with a new flight navigation system (1927-1930) and later antenna measurements together with the German Post (1930-1932) were carried out before Lorenz left the station (Berger, 1998, pp. 90-91).

Obviously, the situation for the Königs Wusterhausen transmitter station was very different. In addition to its central function as the main RPA radio station within the national business communication network, concerts were also broadcast from Königs Wusterhausen (Suckow, 2008, pp. 23-27). Furthermore, Königs Wusterhausen was provided with the latest electron tube transmitters (Thurn, 1921b), (Manteuffel, 1998, pp. 64-65). From July 1924, Königs Wusterhausen was officially allowed to produce a concert every sunday, which was even included in radio programs (e.g. "Der Deutsche Rundfunk", p. 2528). The last concert from Königs Wusterhausen was broadcast on 24 January 1926. In the same year, the transmitter station in Königs Wusterhausen became the central transmitter station of the newly established organisation "Deutsche Welle G.m.b.H." on 7 January 1926. This long wave (LW) transmitter could be received throughout Germany and was therefore called "Deutschlandsender". This is why Königs Wusterhausen remained a well-known name for "broadcasting in Germany" (Suckow, 2008, pp. 33-34).

\section{Conclusions}

In this article, we examined the emergence of the new broadcast medium in Germany shortly after World War I. The most important technical requirements for wireless telephony were known as early as 1905 and the first transmitter concepts were then implemented. Shortly before World War I, there were already numerous "radio amateurs", especially in the USA, who established point-to-point connections with selfbuilt transmitters. First US magazines covering the use of the new broadcasting medium for spreading news and entertaining people were issued in the US. Business people like Hugo Gernsback (Pichler, 2014), who emigrated from Austria to the USA, offered components for building radio transmitters and receivers. However, only a small group of enthusiasts were interested in this technology and its activities were banned after the USA entered the war.

After World War I, the situation changed fundamentally. In all countries involved in the war there were now companies that had developed and manufactured radio technology for military purposes and that had thereby achieved a significant 
market size. These companies were interested in a military to civilian conversion because they lost a lot of sales markets due to the end of the war. On the other hand, there were now tens of thousands of dismissed soldiers from the Army Signal Corps (like in Germany the "Nachrichtentruppe") of these countries who had at least basic knowledge of radio technology and thus had a certain relation with the topic. After all, radio technology had developed in a breathtaking way during World War I and was already at a remarkable level. At the same time, the potential of the broadcasting was recognized as an approach for a new medium that was subsequently implemented in Europe and the USA.

The ways in which radio transmission was implemented differed in the individual countries, which was due to how strictly the legal regulations for the nationwide dissemination of information were handled. In the US, radio amateurs and corporations had a lot of freedom for private initiatives. For this reason the medium of broadcasting was initially organized largely privately and not controlled by the government. In Germany, on the other hand, radio technology was regulated with the laws for post and telegraph services of 1892 (amended in 1908) (Nesper, 1923, p. 13) and thus the ministry responsible for post and telegraphy regulated the use of radio technology.

This also explains the different assessment of the experimental transmission attempts in the transmitter stations in Eberswalde and Königs Wusterhausen. The former Telefunken manager Hans Bredow, responsible for radio technology at RPA, did not want to establish broadcasting for entertaining purposes but wanted to set up a commercial network for the telegraphic distribution ("telegraphic broadcasting") of business news, which also included the former military transmitter station in Königs Wusterhausen. In this context, wireless telephony experiments with a Lorenz-Poulsen transmitter from the Eberswalde test station of C. Lorenz AG were carried out. In this paper it was explained why these experiments are neither about the technology of the later broadcasting nor about the beginning of the broadcast medium. It was not until late in 1923, after numerous interventions by the industry and radio amateurs (Nesper, 1923, introduction, Nesper, 1950, pp. 98-109, Lerg, 1963, pp. 114-132, Soppe, 1976), Bredow felt impelled to establish the medium of broadcasting in Germany. However, in his numerous publications Bredow almost reversed the point of view, claiming that he also initiated entertainment broadcasting in Germany. Although this has been known for a long time, he is still referred to as the "father of broadcasting in Germany". Without diminishing his undoubtedly existing achievements in the technical and organizational construction of broadcasting in Germany, one can at best describe him as one of the pioneers of the new medium in Germany.

Data availability. No data sets were used in this article.
Author contributions. WM devised the main conceptual ideas. AT provided critical feedback and helped to write the manuscript.

Competing interests. The authors declare that they have no conflict of interest.

Disclaimer. Publisher's note: Copernicus Publications remains neutral with regard to jurisdictional claims in published maps and institutional affiliations.

Special issue statement. This article is part of the special issue "Kleinheubacher Berichte 2020".

Acknowledgements. We are grateful to Ljiljana Trajkovic from the School of Engineering Science, Faculty of Applied Sciences, at the Simon Fraser University, Vancouver in Canada, for many advices regarding the final version of this paper.

Financial support. The publication of this article was funded by the open-access fund of Leibniz Universität Hannover.

Review statement. This paper was edited by Jens Anders and reviewed by André Buchau and one anonymous referee.

\section{References}

Ayrton, H. M.: The Electric Arc, The Electrican Printing and Publishing Co., London, 1902.

Berger, K.: Hallo! Hallo! Hier Eberswalde! - Die Versuchsstation für drahtlose Telegraphie in Eberswalde, Museum in der AdlerApotheke, Eberswalde, Germany, 1998.

Beuttel: Redende Zahlen, in: Zur Geschichte der NachrichtenTruppe 1899-1924, edited by: Thiele, F., Breuss, Dresden, Germany, 143-146, 1925.

Bredow, H.: Vier Jahre deutscher Rundfunk, Reichsdruckerei, Berlin, Germany, 1927.

Bredow, H.: Die Wiege des europäischen Rundfunks, in: Aus meinem Archiv - Probleme des Rundfunks, edited by: Bredow, H., Kurt Vowinckel, Heidelberg, Germany, 1950.

Bredow, H.: Im Banne der Ätherwellen, Band I: Der Daseinskampf des Deutschen Funks, Mundus-Verlag, Stuttgart, Germany, 1954.

Bredow, H.: Im Banne der Ätherwellen. Band II: Funk im ersten Weltkriege, Entstehung des Rundfunks, Mundus-Verlag, Stuttgart, Germany, 1956.

Claussen, W. and Nanninga, G.: Festschrift zum 50jährigen Bestehen der Küstenfunkstelle Norddeich Radio 1907-1957, Oberpostdirektion Hamburg, Hamburg, Germany, 1957.

Craft, E. B. and Colpitts, E.H.: Radio Telephony, 7th Midwinter Convention of the American Institute of Electrical Engineers, New York, USA, 21 February 1919, 337-375, 1919. 
Cron, H.: Imperial German Army 1914-18 - Organisation, Structure, Orders of Battle, (Originally published as: Geschichte des Deutschen Heeres im Weltkriege 1914-1918, Berlin, Germany, 1937), Helion \& Company Limited 2001, Solihull, West Midlands, UK, Reprinted 2006.

Dahl, P.: Arbeitersender und Volksempfänger - Proletarische Radio-Bewegung und bürgerlicher Rundfunk bis 1945, Syndicat Autoren- und Verlagsgesellschaft, Frankfurt/M., Germany, 1978.

de Boer, P. A.: à Steringa Idzerda - De Pionier van de RadioOmroep, De Muiderkring N.V., Bussum, The Netherlands, 1969.

Duddel, W. D. B.: On Rapid Variations in the Current through the Direct-Current Arc, Journ. Institution Electrical Engineering, 30, 232-267, 1900.

ETZ-Mitteilung: Drahtlose Telegraphie und Telephonie: Hebung des Funkverkehrs, Elektrotechn. Zeitschr. (ETZ), 40, p. 527, 1919.

FitzGerald, G. F.: On the Driving of Electromagnetic Vibrations by Electromagnetic and Electrostatic Engines, in: The Scientific Writings of the late George Francis Fitzgerald, edited by: Lamor, J., Longmans, Green, and Co., London, UK, 277-281, 1902.

de Forest, L. and Seibt, G.: Grand Opera by Wireless - Metropolitan Opera House in New York City (about a wireless telephony system developed by Lee de Forest and George Seibt), Telephony, 1910, 293-294, 5 March 1910.

Friedewald, M.: Die "Tönenden Funken”: Geschichte eines frühen drahtlosen Kommunikationssystems 1905-1914, GNT-Verlag GmbH, Diepholz, Germany, 1999.

Funk-Mitteilung: Der erste Rundfunksprecher in Europa - "Drahtlose Telephonie" in Königswusterhausen - Versuche seit 1920 Das erste Rundfunkkonzert, Funk, 45, 371-372, 1927.

Gerlach, H.: Erstes Funkkonzert mit Lorenz-Poulsen-Sender, in: 50 Jahre Lorenz, edited by: C. Lorenz AG, Berlin, Germany, 239243, 1930 .

Gilfillan, D.: Pieces of Sound - German Experimental Radio, University of Minnesota Press, Minneapolis (MN), USA, 2009.

Goebel, G.: Nesper, Eugen Heinrich Josef, in: Männer der Funktechnik, edited by: von Weiher, S., VDE-Verlag GmbH, Berlin, Offenbach, Germany, 127-129, 1983.

Goldschmidt, R.: Verfahren und Schaltungsanordnung zur Erzeugung von Hochfrequenzströmen, insbesondere für die drahtlose Telegraphie, DRP 208260, 1907.

Hagen, W.: Das Radio - Zur Theorie und Geschichte des Hörfunks Deutschland/USA, Wilhelm Fink Verlag, München, Germany, 2005.

Herold, K.: Die Radio-Großstation Eilvese, in: 100 Jahre Funktechnik in Deutschland - Funkstionen und Messplätze rund um Berlin, edited by: Klawitter, G., Wissenschaft und Technik Verlag, Berlin, Germany, 45-60, 2002.

Hertz, H.: Untersuchungen ueber die Ausbreitung der elektrischen Kraft, Johann Ambrosius Barth, Leipzig, Germany, 1892.

HOMAG: Eilvese - Radio-Großstation der HOMAGES Hochfrequenz-Maschinen Aktiengesellschaft für drahtlose Telegrapie, HOMAG, Berlin, Germany, 1919.

Jentsch, O.: Telegraphie und Telephonie ohne Draht, Verlag von Julius Springer, Berlin, Germany, 1904.

Kintner, S. M.: Pittburgh's contribution to Radio, Proc. Inst. Radio Eng. (IRE), 20, 1849-1862, 1932.

Klawitter, G.: Die Versuchstation Eberswalde, in: 100 Jahre Funktechnik in Deutschland - Funkstionen und Messplätze rund um
Berlin, edited by: Klawitter, G. Wissenschaft und Technik Verlag, Berlin, Germany, 85-96, 2002.

König, W.: Wilhelm II und die Moderne - Der Kaiser und die technisch-industrielle Welt, Ferdinand Schöningh, Paderborn, München, Wien, Zürich, 2007.

Lavine, A. L.: Circuits of Victory, Country Life Press and Doubleday, Page \& Company, Garden City N.Y., USA, 1921.

Lembke, O.: Oberpostrat Hans Gerlach - 1921-1945 Amtsvorsteher der Hauptfunkstelle Königs Wusterhausen - ein erfolgreicher Rebell der zwanziger Jahre, Nachrichtenblatt für die Vereinigung der höheren Postbeamten, 6, No. 4, 99-106, 1970.

Lerg, W. B.: Die Entstehung des Rundfunks in Deutschland Herkunft und Entwicklung eines publizistischen Mittels, Verlag Josef Knecht, Frankfurt/M., Germany, 1963.

Lerg, W. B.: Hans Bredow - Schwierigkeiten mit einem 100 Geburtstag, Mitteilung Studienkreis Rundfunk und Geschichte, 6, 127-129, 1994.

Lerg, W. B.: Wider die Verballhornung der Bullenwiese zu Eberswalde Denkmalschutz für Rundfunkgeschichte der Funkgeschichte?, Mitteilung Studienkreis Rundfunk und Geschichte, 20, 28-36, 1980.

Hahnemann, W. M., and Steudel, H. A. (Eds.): 50 Jahre Lorenz, 1880-1930, Festschrift der C. Lorenz Aktiengesellschaft, BerlinTempelhof, Förster \& Borries, Berlin, Germany, 1931.

Ludendorff, E.: Meine Kriegserinnerungen 1914-1918, Ernst Siegfried Mittler und Sohn Verlagsbuchhandlung, Berlin, Germany, 1919.

Maier, H.: Drahtlose Telegraphie im Schützengraben? Die "Tafunk" und ihre Wissenschaftler im Ersten Weltkrieg, in: Geschichte der elektrischen Kommunikation bis zum Smartphone, edited by: Titze, A., Klartext-Verlag, Essen, Germany, 39-83, 2019.

Manteuffel, P.: Die Hauptfunkstelle Königs Wusterhausen, in: 100 Jahre Funktechnik in Deutschland - Funksendestellen rund um Berlin, edited by: Klawitter, G., Wissenschaft und Technik Verlag, Berlin, Germany, 62-78, 1998.

Marple, A.: Wireless Music With Your Meals, The Electrical Experimenter, 4, p. 84, 1916.

Mathis, W.: Drahtlos aus Eberswalde - Lorenz-Poulsen Lichtbogensender für den Rundfunk, in: Geschichte der elektrischen Kommunikation bis zum Smartphone, edited by: Titze, A., Klartext-Verlag, Essen, Germany, 85-110, 2019.

Mehle, W.: Hier ist Königs Wusterhausen ... Eine Erinnerung an die Geburtsstätte des Deutschen Rundfunks, Arch. f. Deutsche Postschichte, 2, 25-, 1955.

Meißner, A.: Die Zeit der Maschinensender, in: Festschrift zum 50 jährigen Jubiläum der Telefunken Gesellschaft für drahtlose Telegraphie m.b.H. (gleichzeitig als 100. Ausgabe der Telefunken-Zeitung: Telefunken-Zeitung, 26. Jg., Nr. 100, Mai 1953), edited by: Telefunken GmbH, Berlin, Germany, 1953.

Museum Eberswalde (Ed.): Kommunikation mit Strom - Telefon und Rundfunk, authors: Titze, A. and Mathis, W., Stadt Eberswalde, Eberswalde, Germany, 2020.

Naber, H. : Ruttmann \& Konsorten - Über die früheren Beziehungen zwischen Hörspiel und Film, Mitteilung Studienkreis Rundfunk und Geschichte, 32, 5-20, 2006.

Nairz, O.: Eine Telefunken-Ausstellung, Elektrotechn. Zeitschr. (ETZ), 40, 482-484, 1919.

Nesper, E.: Handbuch der Drahtlosen Telegraphie und Telephonie, Vol. 2, Verlag von Julius Springer, Berlin, Germany, 1921. 
Nesper, E.: Der Radio-Amateur - "Broadcasting", Verlag von Julius Springer, Berlin, Germany, 1923.

Nesper, E.: Ein Leben für den Funk - Wie der Rundfunk entstand, R. Oldenbourg Verlag, München, Germany, 1950.

Nestel, W.: Pungs, Leo Wilhelm Julius, in: Männer der Funktechnik, edited by: von Weiher, S., VDE-Verlag GmbH, Berlin, Offenbach, 141-143, 1983.

Pichler, F.: Hugo Gernsback und seine technischen Magazine, Linz: Trauner Druck \& Co KG, Austria, 2014.

Poulsen, V.: Method of Producing Alternating Currents with a High Number ov Vibrations, Patent US789449A, 1903.

Pressestelle HQ Mézières-Charleville: Kämpfe der Heeresgruppe Deutscher Kronprinz 1917, bearbeitet von den OffizierKriegsberichterstattern der Heeresgruppe, Felddruckerei A.O.K. 5, Germany, 1917.

Pungs, L.: German Patent, DRP 281440, issued 15 July 1913.

Pungs, L.: Die neuere Entwicklung der drahtlosen Telephonie, Elektrotech. Zeitschr., 43, p. 1219, 1922.

Pungs, L.: Die Steuerung von Hochfrequenzströmen durch Eisendrosseln mit überlagerter Magnetisierung, Elektrotechn. Zeitschr., 44, 78-81, 1923.

Pungs, L.: Comments on the History of Parametric Transducers, Proc. IRE, 49, p. 378, 1961.

Ross, D.: Hans Bredow - Legende und Wirklichkeit - Betrachtungen zu einem Buch von Winfrid B. Lerg, Rundfunk und Fernsehen, 14, 150-168, 1966.

Rundfunk-Mitteilung, Der Deutsche Rundfunk, 2, 26 October 1924.

Schott: Geschichtlicher Überblick über die Entwicklung unserer Truppe, in: Zur Geschichte der Nachrichten-Truppe 1899-1924, edited by: Thiele, F., Breuss, Dresden, Germany, 25-93, 1925.

Schwarzkopf, E.: Rundfunk-Rückblick, Der Deutsche Rundfunk, 2, 2411-2413, p. 2603, 1924.

SEG: Zur Geschichte des Funkfernsprechens, Elektrisches Nachrichtenwesen, 12, p. 98, 1934.

Seitz, F.: The Cosmic Inventor: Reginald Aubrey Fessenden (18661932), Transactions of the American Philosophical Society, New Series, 89, 1-77, 1999.

Simon, H. T.: Akustische Erscheinungen am electrischen Flammenbogen, Ann. Phys., 300, 233-239, 1898.

Soppe, A.: Einführung des Rundfunks in Deutschland, in: Massen, Medien, Politik, edited by: Haug, W. F., Argument-Verlag, Karlsruhe, Germany, 1976.

Star Tribune News: Music by Wireless to Become Possiblity - System Perfect Whereby Tunes May be Sent Hundreds of Miles Baron Egbert Von Lepel Is the Inventor of the Very Simple Contrivance, Star Tibune, Minneapolis, Minnesota, USA, p. 21, 15 August 1909.
Stock, R.: Geschichte des Militärfunks, Militärfunk, Berlin, Germany, 2011.

Strauß, S.: Das Fehlerbauch des Radioamateurs, Julius Springer, Berlin, Germany, 1925.

Sukow, R. (Ed.): ... Hier Königs Wusterhausen auf Welle 2700 ... - Beiträge zur Funkgeschichte in Königs Wursterhausen, 3rd. Edn., Druckerei Fröhlich, Bestensee, Germany, 2008.

Telefunken: Berlin-Königswusterhausen - Die Großstation der deutschen Heeresverwaltung, Telefunken-Zeitung, 1, 80-85, 1912.

Telefunken: Berlin-Königswusterhausen - Die Großstation der deutschen Heeresverwaltung, Telefunken-Zeitung, 3, 35-37, 1919.

Telefunken Transradio (Ed.): Festschrift zur Einweihung der Grossfunkstelle Nauen am 29.9.20, Telefunken Transradio, Berlin, Germany, 1920.

Thiele, F.: Zur Geschichte der Nachrichten-Truppe 1899-1924, Dr. Wedekind \& Co., Berlin, Germany, 1925.

Thompson, S. F.: On the properties of a body having a negative electric resistance, The Electrician, 37, 316-318, 3 July 1896.

Thurn, H.: Die internationale Verbreitung der Funkentelegraphie, Elektrotech. Zeitschr., 31, No.8, 188-190, 1910.

Thurn, H.: Die deutsche Funkentelegraphie im Weltkriege, Jahrbuch des Norddeutschen Lloyd, 1918/19, 93-128, 1919.

Thurn, H.: Die Indienststellung der Funkentelegraphie für öffentliche Verkehrszwecke, Elektrotechn. Zeitschr. (ETZ), 40, 545-546, 1919.

Thurn, H.: Die Poulsenanlage bei der Hauptfunkstelle in Königswusterhausen, Telegraphen- u. Fernsprechtechnik., 9, 3742, and 55-60, 1920.

Thurn, H.: Der drahtlose Wirtsschafts-Rundspruchdienst, Elektrotechn. Zeitschr. (ETZ), 42, 1355-1357, 1921.

Thurn, H.: $10 \mathrm{~kW}-$ Röhrensender in Königswusterhausen, Elektrotechn. Zeitschr. (ETZ), 42, 1415-1418, 1921.

The Times News: Decision by the patent Office, January 8, 1911, The Times, p. 5, 9 January 1911.

Weichart, F.: In 14 Tagen - einen Sender für Berlin!, in: Rundfunk Jahrbuch 1930, edited by: Reichs-Rundfunk Gesellschaft, Union Deutsche Verlagsgesellschaft 1930, Berlin, Germany, 4352, 1930.

Weichart, F.: Erinnerungen eines verdienten Funkpioniers aus seinem Leben und Wirken (überliefert und realisiert von Karl Neumann and presented by GFGF e.V.), Verlag Dr. Rüdiger Walz, Kelkheim, Germany, 1997.

Wolfschmidt, G. (Ed.): Heinrich Hertz (1857-1894) and the Development of Communication, Proc. Sympos. History of Science, Hamburg, 8-12 October 2007, Books on Demand GmbH, Norderstedt bei Hamburg, Germany, 2008. 